\title{
High level expression and biochemical characterization of an alkaline serine protease from Geobacillus stearothermophilus to prepare antihypertensive whey protein hydrolysate
}

\author{
Chang Chang', Siyi Gong', Zhiping Liu', Qiaojuan Yan² and Zhengqiang Jiang ${ }^{1 *}$
}

\begin{abstract}
Background: Proteases are important for hydrolysis of proteins to generate peptides with many bioactivities. Thus, the development of novel proteases with high activities is meaningful to discover bioactive peptides. Because natural isolation from animal, plant and microbial sources is impractical to produce large quantities of proteases, gene cloning and expression of target protease are preferred.

Results: In this study, an alkaline serine protease gene (GsProS8) from Geobacillus stearothermophilus was successfully cloned and expressed in Bacillus subtilis. The recombinant GsProS8 was produced with high protease activity of $3807 \mathrm{U} / \mathrm{mL}$ after high cell density fermentation. GsProS8 was then purified through ammonium sulfate precipitation and a two-step chromatographic method to obtain the homogeneous protease. The molecular mass of GsProS8 was estimated to be $27.2 \mathrm{kDa}$ by sodium dodecyl sulphate-polyacrylamide gel electrophoresis (SDSPAGE) and $28.3 \mathrm{kDa}$ by gel filtration. The optimal activity of GsProS8 was found to be $\mathrm{pH} 8.5$ and $50{ }^{\circ} \mathrm{C}$, respectively. The protease exhibited a broad substrate specificity and different kinetic parameters to casein and whey protein. Furthermore, the hydrolysis of whey protein using GsProS8 resulted in a large amount of peptides with high angiotensin-l-converting enzyme (ACE) inhibitory activity (IC $C_{50}$ of $0.129 \mathrm{mg} / \mathrm{mL}$ ).
\end{abstract}

Conclusions: GsProS8 could be a potential candidate for industrial applications, especially the preparation of antihypertensive peptides.

Keywords: Alkaline serine protease, Geobacillus stearothermophilus, Bacillus subtilis, Whey protein hydrolysate, ACE inhibitory activity

\footnotetext{
* Correspondence: zhajiang@cau.edu.cn

'Key Laboratory of Food Bioengineering (China National Light Industry), College of Food Science and Nutritional Engineering, China Agricultural University, No. 17 Qinghua Donglu, Beijing 100083, China

Full list of author information is available at the end of the article
} 


\section{Background}

Microbial serine proteases (EC 3.4.21.14) are one of most important proteases to be applied in different food fields, such as meat tenderization, cheese ripening, flavor development, baking, and preparation of bioactive peptides [1]. They are composed of serine residue forming a catalytic triad with aspartic acid and histidine in the active site, which can be inactivated by phenylmethylsulfonylfluoride (PMSF), diodopropyl fluorophosphate (DFP) and chymostatin [2]. Alkaline serine proteases have mainly been produced by Bacillus species, which have abilities to tolerate $\mathrm{pH}$ variance to secrete much amount of proteases $(>20 \mathrm{~g} /$ L protein) [1]. Serine proteases from Bacillus gibsonii, Bacillus subtilis KJ-21 and Bacillus licheniformis have been patented to be suitable for use in cleaning fabrics, producing fermented food, and hydrolyzing milk protein to prepare hypoallergenic formula, respectively [3-5].

Geobacillus stearothermophilus is extensively distributed in the soil and hot spring, and is a rich source of proteases [6-8]. An alkaline serine protease from $G$. stearothermophilus F1 (presented in composed oil palm branches) was firstly reported by Rahman and coworkers [9], who had further cloned and expressed the gene in Escherichia coli [7]. Thereafter, Pichia pastoris was used for secretory expression of the protease gene from $G$. stearothermophilus F1, to solve the formation of inclusion bodies and incorrect protein folding induced by $E$. coli expression system, but the expression level was still low (protease activity of $4.13 \mathrm{U} / \mathrm{mL}$ ) [10]. Meanwhile, another alkaline serine protease from G. stearothermophilus strains B-1172 has also been cloned and expressed in $E$. coli to exhibit protease activities of $69 \mathrm{U} / \mathrm{mL}$ [8]. As high protease activity and $\mathrm{pH}$ stability are important for industrial applications, a proper expression system will be essential to improve the expression level of the target protease genes from G. stearothermophilus [1].

Bacillus subtilis, a generally recognized as safe (GRAS) bacterium, is widely used as an expression host to secrete foreign proteases directly into culture medium. It is considered as an efficient expression system with several advantages, such as rapid growth rate to result in short fermentation cycles, distinguished ability to secrete significant amounts of proteins into the extracellular medium, easy cultivation and genetic manipulation [1]. A variety of proteases have been successfully expressed in B. subtilis, including an alkaline protease (AprE) from Bacillus licheniformis 2709 [11, 12], a serine protease (AprB) from $\mathrm{Ba}$ cillus sp. strain B001 [13], a neutral protease (NprT) from G. stearothermophilus [14], and alkaline serine proteases from Bacillus clausii (aprE) $[15,16]$. It has been reported that an alkaline protease from $B$. clausii yielded a protease activity of $1020 \mathrm{U} / \mathrm{mL}$ in B. subtilis as compared to $347 \mathrm{U} /$ $\mathrm{mL}$ in the wild type strain [15]. A thermolabile alkaline protease from B. licheniformis 2709 showed a high protease production of $6280 \mathrm{U} / \mathrm{mL}$ when it was expressed in B. subtilis [11]. However, some of Bacillus species directly secreted alkaline serine proteases to present high protease activities without expression in B. subtilis. Two proteases (SAPB and SAPRH) were hyper-produced $(6500 \mathrm{U} / \mathrm{mL}$ and $9000 \mathrm{U} / \mathrm{mL}$ ) from Bacillus pumilus strain CBS and Bacillus safensis RH12 under optimized fermentations, as compared with crude protease activities of 310 $\mathrm{U} / \mathrm{mL}$ and $450 \mathrm{U} / \mathrm{mL}$, respectively $[17,18]$.

Protein hydrolysis to yield bioactive hydrolysates and peptides is an interesting field with much attentions. Antioxidant, antihypertensive, and antidiabetic potentials are most commonly reported for protein hydrolysates, which may be applied as nutraceuticals and functional food ingredients, potentially contributing to food quality and promoting human health [19]. Particularly, antihypertensive hydrolysates inhibiting angiotensin-I-converting enzyme (ACE), which is very relevant in the regulation of the cardiovascular function and blood pressure, have been abundantly investigated [1]. Recent studies have been focused on the production of antihypertensive hydrolysates using non-commercial proteases, such as alkaline serine proteases from Bacillus sp. CL18 [20], Maclura pomifera [21], and Cucurbita ficifolia [22].

The objective of this study was to clone and express a serine protease gene from G. stearothermophilus CAU209 (GsProS8) in B. subtilis to improve its activity (as compared with $69 \mathrm{U} / \mathrm{mL}$ in E. coli) [8]. The recombinant protease was then purified and characterized to evaluate its potential application in the preparation of antihypertensive hydrolysates.

\section{Results}

\section{Expression and purification of GsProS8}

The open reading frame (ORF) of GsProS8 with $1149 \mathrm{bp}$ encoding 383 amino acids was cloned (Fig. S1). The mature protein had a predicted molecular mass of $39.0 \mathrm{kDa}$. There was no signal peptide in the deduced amino acid sequence based on the analysis by SignalP 4.0. According to the molecular mass determination, a pro-peptide of 107 amino acids was predicted. Thus, the amino acid sequence of GsProS8 consisted of the pro-peptide sequence (1-107) and the mature peptide sequence (108383). It was found the amino acid sequence of GsProS8 was same as an alkaline serine protease from G. stearothermophilus B-1172 (GenBank: EU181368) that was expressed in E. coli BL21 [8].

Thereafter, GsProS8 was successfully expressed in $B$. subtilis WB600 under the control of $\mathrm{P} 43$ promotor [14]. B. subtilis WB600 transformant was then cultivated in a 5 $\mathrm{L}$ fermentor. The protease activity and protein content showed a continuous increment with time, up to a maximum of $3807 \mathrm{U} / \mathrm{mL}$ and $2.08 \mathrm{mg} / \mathrm{mL}$ at $114 \mathrm{~h}$, respectively (Fig. 1a). By sodium dodecyl sulphate-polyacrylamide 
(a)

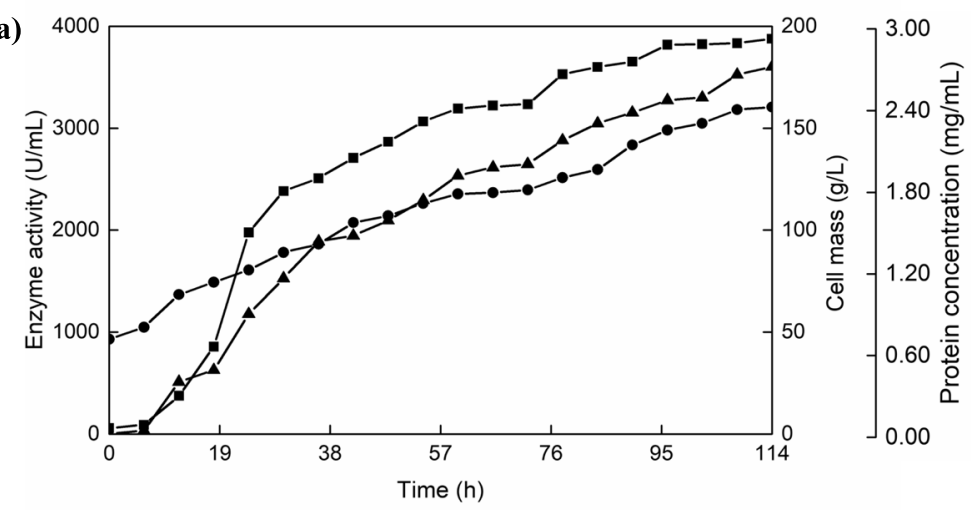

(b) $\mathrm{kDa}$

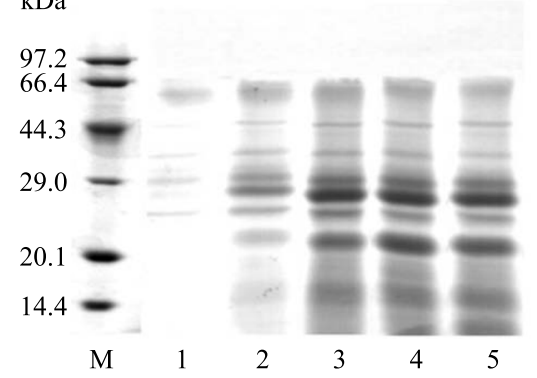

Fig. 1 High cell density fermentation of GsProS8 expressed in B. subtilis. a enzyme activity ( $\square$, protein concentration and cell mass the supernatants. $\mathbf{b}$ extracellular protein analysis by SDS-PAGE during fermentation. Lane M, the protein marker; lanes 1-5, the supernatants collected at $24 \mathrm{~h}, 48 \mathrm{~h}, 72 \mathrm{~h}, 96 \mathrm{~h}$, and $114 \mathrm{~h}$, respectively. The full-length gel was presented in Fig. S2

gel electrophoresis (SDS-PAGE), a major protein band around $27 \mathrm{kDa}$ was detected in the fermented medium (Fig. 1b).

After the fermentation, GsProS8 was purified 2.1-fold to homogeneity with a yield of $23.6 \%$. The specific activity of the protease was increased from $1679.1 \mathrm{U} / \mathrm{mg}$ to $3559.7 \mathrm{U} / \mathrm{mg}$ (Table 1). The homogeneity of purified GsProS8 was confirmed via a single smeared band at $27.2 \mathrm{kDa}$ by SDS-PAGE (Fig. 2), while the native molecular mass was determined to be $28.3 \mathrm{kDa}$ by gel filtration (Fig. 3). This indicated that GsProS8 is a monomer. Because the conversion process of the primary gene product into the mature enzyme can be mediated by active subtilisin to cleave off the pro-peptide sequence in the extracellular medium during the secretion [11], the molecular mass of purified GsProS8 was lower than the predicted value of $39.0 \mathrm{kDa}$. Moreover, the purified GsProS8 was evaluated and a clear band of proteolytic activity was observed in the zymogram (Fig. 2).

Biochemical properties and kinetic parameters of GsProS8 The highest activity of GsProS8 was observed at $\mathrm{pH} 8.5$ (Fig. 4a). The protease was stable at $\mathrm{pH} 5.5-8.5$ to retain more than $90 \%$ of the activity (Fig. 4b). The optimal temperature of GsProS8 was found to be $50^{\circ} \mathrm{C}$ (Fig. 4c). It was stable up to $65^{\circ} \mathrm{C}$, retaining more than $80 \%$ of the

Table 1 Purification summary of GsPros8

\begin{tabular}{llllll}
\hline Purification step & ${\text { Total activity }(\mathbf{U})^{\mathbf{a}}}^{\mathbf{2}}$ & ${\text { Total protein } \mathbf{( m g})^{\mathbf{b}}}$ & Specific activity $(\mathbf{U} / \mathbf{m g})$ & Purification factor & Yield (\%) \\
\hline Crude protease & $116,250 \pm 2089.3$ & $68.5 \pm 4.1$ & $1697.1 \pm 30.2$ & 1.0 & 100.0 \\
Ammonium sulfate precipitation & $86,460 \pm 1965.2$ & $41.6 \pm 1.9$ & $2078.4 \pm 47.5$ & 1.2 & 74.4 \\
SPFF & $50,806 \pm 190.5$ & $22.4 \pm 5.4$ & $2268.1 \pm 9.1$ & 1.3 & 43.7 \\
QSFF & $27,409 \pm 373.9$ & $7.7 \pm 1.2$ & $3559.7 \pm 48.4$ & 2.1 & 23.6
\end{tabular}

${ }^{a}$ Enzymatic reaction was carried out using casein as a substrate at $50{ }^{\circ} \mathrm{C}$ in $0.05 \mathrm{~mol} / \mathrm{L} \mathrm{MOPS}$ buffer $(\mathrm{pH} 8.5$ )

${ }^{\mathrm{b}}$ Total protein was measured using BSA as standard by the Lowry method 


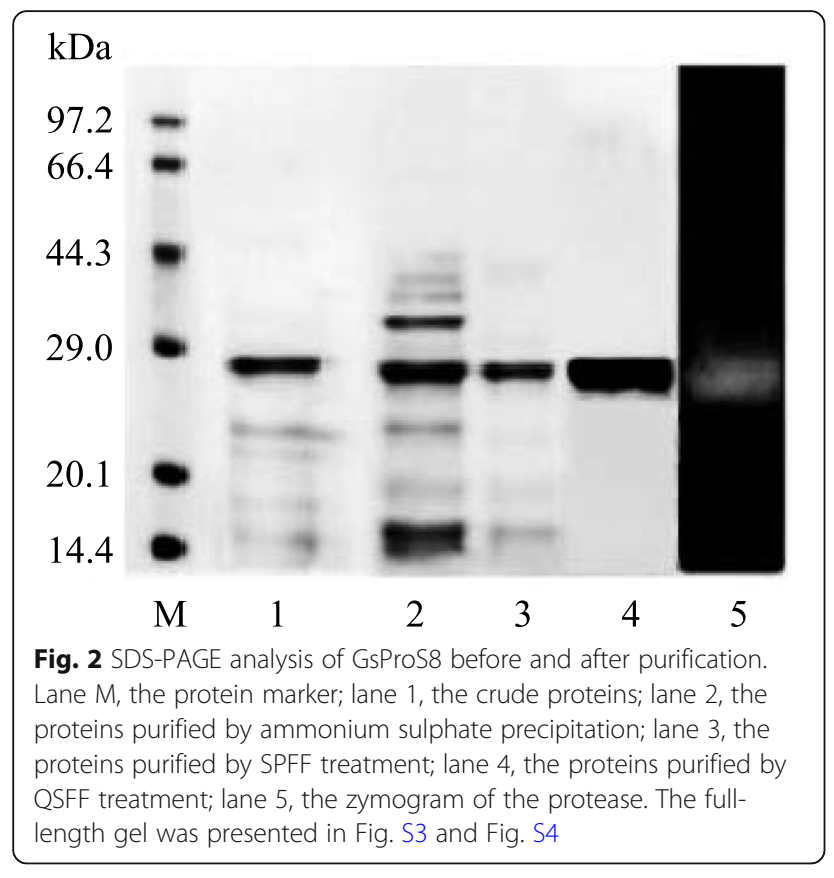

activity (Fig. 4d). Protease inhibitors were subjected to identify groups at the active site of GsProS8. Pepstatin A (aspartic protease inhibitor) and iodoacetamide (cysteine protease inhibitor) slightly affected the protease activity, indicating that aspartate residue and - $\mathrm{SH}$ group did not work in the protease activity of GsProS8. The presence of ethylenediaminetetraacetic acid (EDTA, metalloenzyme inhibitor) at $1 \mathrm{mM}$ and $4 \mathrm{mM}$ inhibited 30.5 and $40.5 \%$ of the protease activity, respectively, revealing that some ions may be important for the stability and activity of GsProS8. The strong inhibition of 95.4 and $99.7 \%$ at $1 \mathrm{mM}$ and $4 \mathrm{mM}$ of PMSF (serine protease inhibitor) suggested that GsProS8 belongs to the serine protease class (Table 2).

The effects of various metal ions on the protease activity were assessed (Table 3). The protease activity of GsProS8 was not affected by $\mathrm{Mg}^{2+}$, but slightly impacted by $\mathrm{Ca}^{2+}(93.7 \%)$ and $\mathrm{Na}^{+}(91.4 \%)$. The moderate reduction in the protease activity of GsProS8 was observed in the presence of $\mathrm{Mn}^{2+}(78.9 \%), \mathrm{Zn}^{2+}(78.1 \%), \mathrm{Co}^{2+}$ (76.6\%), $\mathrm{Ni}^{2+}(66.1 \%)$, and $\mathrm{Cu}^{2+}(40.7 \%)$. In addition, GsProS8 exhibited the highest protease activity towards casein $(100 \%)$, followed by whey protein $(92.1 \%)$ and skim milk powder (85.5\%). The protease showed a broad substrate specificity towards hemoglobin $(60.7 \%)$, soybean protein isolate $(56.7 \%)$, bovine serum albumin (BSA, 45.7\%), protamine (37.5\%), myoglobin (36.9\%), and azocasein (31.2\%). However, GsProS8 displayed low activity towards gelatin (10.5\%) (Table 4). The kinetic parameters of the purified GsProS8 were determined using casein and whey protein as substrates. The values of $K_{\mathrm{m}}$ and $V_{\max }$ were $7.37 \mathrm{mg} / \mathrm{mL}$ and $13.35 \mathrm{mg} / \mathrm{mL}$, $231.45 \mu \mathrm{mol} / \mathrm{mg}$.min and $122.96 \mu \mathrm{mol} / \mathrm{mg}$.min for casein and whey protein, respectively (Table 5 ).

\section{Preparation of antihypertensive whey protein hydrolysates by GsProS8}

The optimization of whey protein hydrolyzation by GsProS8 based on the orthogonal experimental design is shown in Table 6. The correlation coefficient value (R) demonstrated that whey protein concentration was the most affective factor $(R=19.1)$ on the peptide contents of whey protein hydrolysates, followed by temperature, $\mathrm{pH}$ and time. In addition, higher $\mathrm{K}$ value in each column showed the stronger impacts of the level $(1,2$, or 3$)$ on the peptide contents. Therefore, evaluated by $\mathrm{K}$ values, the optimized hydrolysis conditions to prepare whey protein
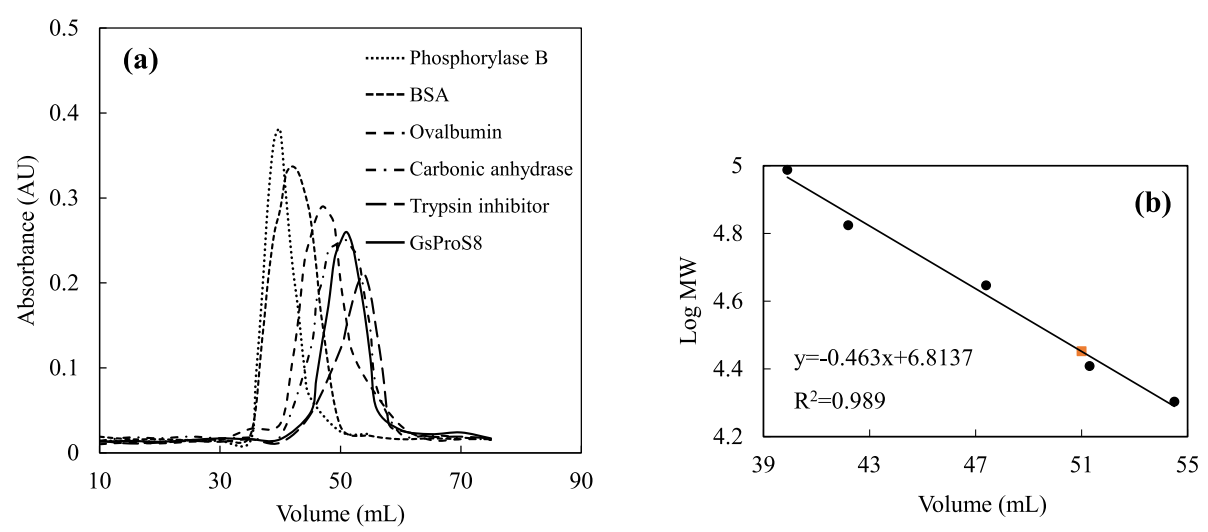

Fig. 3 Molecular mass estimation of GsProS8 ( $\mathbf{a}$ ) by gel filtration chromatography. a: the ultraviolet (UV) chromatogram; b: the calibration curve to calculate molecular mass of GsProS8. Standard proteins $(\bullet)$, including trypsin inhibitor (20.1 kDa), carbonic anhydrase (29.0 kDa), ovalbumin (44.3 kDa), bovine serum albumin (BSA, 66.4 kDa) and phosphorylase B (97.2 kDa) 

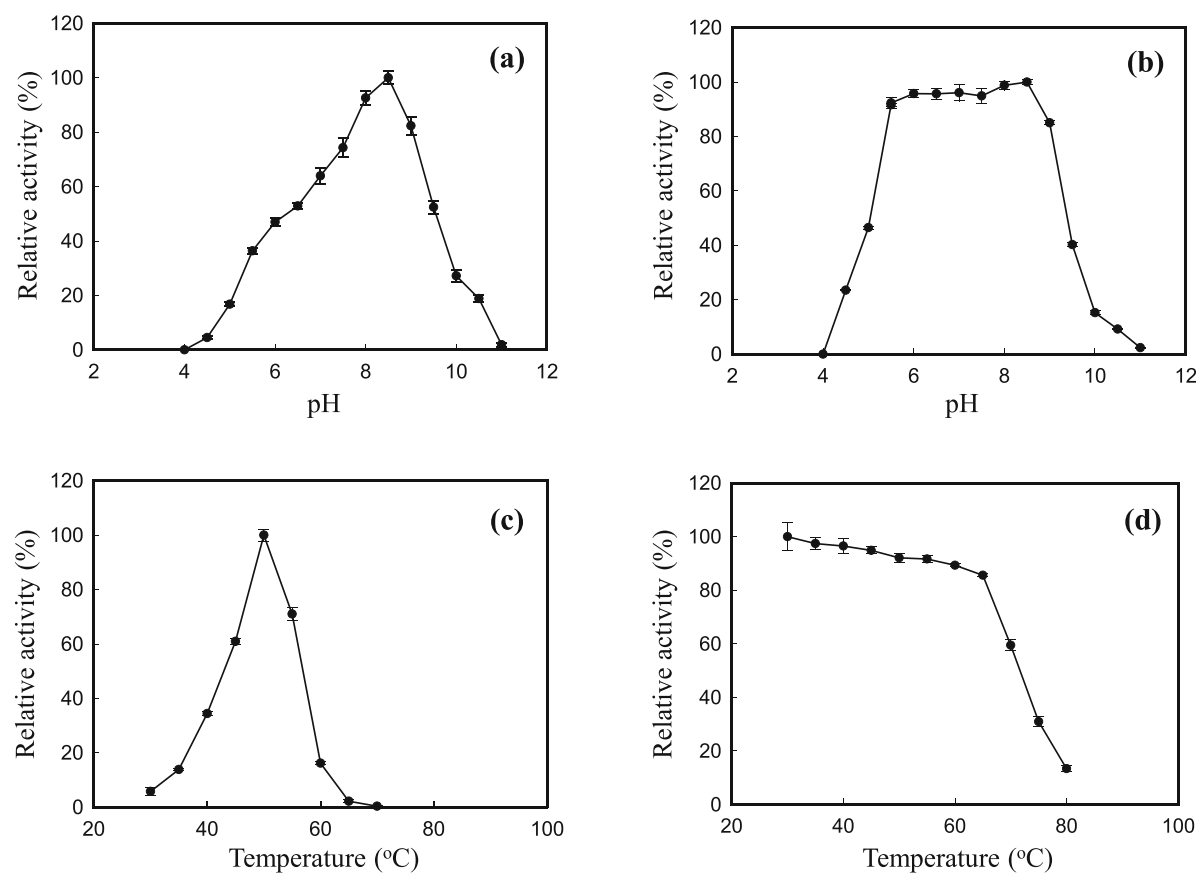

Fig. 4 Optimal pH (a), pH stability (b), optimal temperature (c), and thermostability (d) of GsProS8. The influence of pH on GsProS8 activity was measured in $0.05 \mathrm{~mol} / \mathrm{L}$ of different buffers at $40^{\circ} \mathrm{C}$. For the optimal $\mathrm{pH}$, the relative activity (\%) was determined against the specific activity of $3916 \mathrm{U} / \mathrm{mg}$. To determine $\mathrm{pH}$ stability against the optimal activity $(2631 \mathrm{U} / \mathrm{mg}$, defined as $100 \%$ relative activity), GsProS8 was incubated in various buffers $(0.05 \mathrm{~mol} / \mathrm{L})$ at $40^{\circ} \mathrm{C}$ for $30 \mathrm{~min}$. For optimal temperature, GsProS8 activity was tested at different temperatures in MOPS buffer $(0.05 \mathrm{~mol} / \mathrm{L}$, at $\mathrm{pH} 8.5)$ in contrast to the specific activity of $3916 \mathrm{U} / \mathrm{mg}$. The thermostability of GsProS8 was assayed against the optimal activity (3915 U/mg, defined as 100\% relative activity) after incubation at different temperatures for $30 \mathrm{~min}$

hydrolysate by GsProS8 should be performed using $11 \%$ $(\mathrm{w} / \mathrm{v})$ of whey protein at $\mathrm{pH} 8.0$ and $60^{\circ} \mathrm{C}$ for $6 \mathrm{~h}$.

The performance of GsProS8 was compared with commercial proteases in the preparation of antihypertensive whey protein hydrolysates (Fig. 5). The whey protein hydrolysate prepared by Flavourzyme contained the highest $(p<0.05)$ peptide content (52.02\%) with the strongest ACE inhibitory activity $\left(\mathrm{IC}_{50}\right.$ of $\left.0.116 \mathrm{mg} / \mathrm{mL}\right)$, followed by the hydrolysates generated by GsProS8 ( $\mathrm{IC}_{50}$ of $0.129 \mathrm{mg} / \mathrm{mL}$ ) and
Alcalase ( $\mathrm{IC}_{50}$ of $0.143 \mathrm{mg} / \mathrm{mL}$ ). Nevertheless, both of trypsin and Protamex were less $(p<0.05)$ suitable to prepare antihypertensive whey protein hydrolysates, because of the higher $\mathrm{IC}_{50}$ values $(0.197 \mathrm{mg} / \mathrm{mL}$ and $0.192 \mathrm{mg} / \mathrm{mL}$ ).

\section{Discussion}

G. stearothermophilus can produce extracellular neutral and alkaline proteases $[8,14]$. Many researches have explored alkaline serine proteases from several strains of

Table 2 Effect of selective protease inhibitors on the protease activity of GsProS8. Different letters (a-f) on the same column indicated significant $(p<0.05)$ differences among samples*

\begin{tabular}{llll}
\hline Inhibitor & Concentration $(\mathbf{m M})$ & Specific activity $(\mathbf{U} / \mathbf{m g})$ & Relative activity (\%) \\
\hline Pepstatin A & 0.01 & $3201.0 \pm 49.7^{\mathrm{a}}$ & 89.9 \\
& 0.02 & $2993.5 \pm 52.0^{\mathrm{b}}$ & 84.1 \\
PMSF & 1 & $162.3 \pm 20.3^{\mathrm{e}}$ & 4.6 \\
& 4 & $10.3 \pm 2.3^{\mathrm{f}}$ & 0.3 \\
lodoacetamide & 1 & $3277.0 \pm 15.8^{\mathrm{a}}$ & 92.1 \\
& 4 & $2901.0 \pm 36.2^{\mathrm{b}}$ & 81.5 \\
EDTA & 1 & $2475.7 \pm 29.4^{\mathrm{c}}$ & 69.5 \\
& 4 & $2118.2 \pm 6.8^{\mathrm{d}}$ & 59.5 \\
\hline
\end{tabular}

${ }^{*}$ Enzymatic reaction was carried out using casein as a substrate at $50{ }^{\circ} \mathrm{C}$ in $0.05 \mathrm{~mol} / \mathrm{L}$ MOPS buffer (pH 8.5$)$. Specific activity was shown as mean \pm SD ( $n=3$ ). Relative activity was expressed as a percentage of the activity in the absence of inhibitors (the control) 
Table 3 Effect of metal ions on the protease activity of GsProS8. Different letters (a-g) on the same column indicated significant $(p<0.05)$ differences among samples*

\begin{tabular}{lll}
\hline Metal ion & Specific activity $(\mathbf{U} / \mathbf{m g})$ & Relative activity (\%) \\
\hline None & $3559.7 \pm 48.4^{\mathrm{a}}$ & 100.0 \\
$\mathrm{Mg}^{2+}$ & $3593.4 \pm 2.3^{\mathrm{a}}$ & 100.9 \\
$\mathrm{Ca}^{2+}$ & $3334.5 \pm 15.8^{\mathrm{b}}$ & 93.7 \\
$\mathrm{Na}^{+}$ & $3254.4 \pm 18.1^{\mathrm{c}}$ & 91.4 \\
$\mathrm{Ni}^{2+}$ & $2354.5 \pm 9.0^{\mathrm{f}}$ & 66.1 \\
$\mathrm{Mn}^{2+}$ & $2808.6 \pm 24.9^{\mathrm{d}}$ & 78.9 \\
$\mathrm{Co}^{2+}$ & $2726.4 \pm 5.0^{\mathrm{e}}$ & 76.6 \\
$\mathrm{Zn}^{2+}$ & $2779.8 \pm 6.8^{\text {de }}$ & 78.1 \\
$\mathrm{Cu}^{2+}$ & $1450.5 \pm 9.0^{\mathrm{g}}$ & 40.7 \\
\hline
\end{tabular}

*Enzymatic reaction was carried out using casein as a substrate at $50^{\circ} \mathrm{C}$ in $0.05 \mathrm{~mol} / \mathrm{L}$ MOPS buffer (pH 8.5). Specific activity was shown as mean \pm SD $(n=3)$. Relative activity was expressed as a percentage of the activity in the absence of metal ions (the control)

G. stearothermophilus, such as strain F1 [7], strain B1172 [8], and strain AP-4 [6]. In the present study, an alkaline serine protease gene (GsProS8) from G. stearothermophilus CAU209 was cloned and expressed in $B$. subtilis WB600. Although GsProS8 shared the same amino acid sequence with the reported protease from $G$. stearothermophilus B-1172 [8], the protease activity of GsProS8 (3807 U/mL) after high cell density fermentation (Fig. 1a) was much higher than the proteases from the strain AP-4 (250 U/mL) [6], the strain F1 (1500 U/ $\mathrm{mL})$ and the strain B-1172 $(69 \mathrm{U} / \mathrm{mL})$ that were expressed in $E$. coli $[7,8]$. This may be attributed to the detrimental effects on the $E$. coli by the intracellular

Table 4 Substrate specificity of GsPros8. Different letters (a-h) on the same column indicated significant $(p<0.05)$ differences among samples*

\begin{tabular}{lll}
\hline Substrate & $\begin{array}{l}\text { Specific activity } \\
(\mathbf{U} / \mathbf{m g})\end{array}$ & $\begin{array}{l}\text { Relative activity } \\
(\%)\end{array}$ \\
\hline Casein & $3560.5 \pm 15.8^{\mathrm{a}}$ & 100 \\
Whey protein & $3277.0 \pm 19.8^{\mathrm{b}}$ & 92.1 \\
Skim milk powder & $3044.8 \pm 13.6^{\mathrm{c}}$ & 85.5 \\
Hemoglobin & $2161.4 \pm 54.2^{\mathrm{d}}$ & 60.7 \\
Soybean protein isolate & $2025.8 \pm 45.2^{\mathrm{d}}$ & 56.9 \\
Bovine serum albumin & $1627.2 \pm 22.6^{\mathrm{e}}$ & 45.7 \\
Protamine & $1333.4 \pm 6.8^{\mathrm{f}}$ & 37.5 \\
Myoglobin & $1312.9 \pm 33.9^{\mathrm{f}}$ & 36.9 \\
Azocasein & $1109.5 \pm 0.1^{\mathrm{g}}$ & 31.2 \\
Gelatin & $374.1 \pm 1.6^{\mathrm{h}}$ & 10.5
\end{tabular}

*Enzymatic reaction was carried out using different substrates at $50^{\circ} \mathrm{C}$ in 0.05 $\mathrm{mol} / \mathrm{L}$ MOPS buffer ( $\mathrm{pH} 8.5)$. Specific activity was shown as mean $\pm \mathrm{SD}(n=3)$. Relative activity was expressed as a percentage of the activity when casein as a substrate (the control)
Table 5 Kinetic parameters of GsProS8 for casein and whey protein. Different letters (a-b) on the same column indicated significant $(p<0.05)$ differences among samples*

\begin{tabular}{lllll}
\hline Substrate & $\begin{array}{l}\boldsymbol{V}_{\max } \\
(\boldsymbol{\mu m o l} / \mathbf{m g} \cdot \mathbf{m i n})\end{array}$ & $\begin{array}{l}\boldsymbol{K}_{\mathbf{m}} \\
(\mathbf{m g} / \mathbf{m L})\end{array}$ & $\begin{array}{l}\boldsymbol{k}_{\text {cat }} \\
\left(\mathbf{s}^{-1}\right)\end{array}$ & $\begin{array}{l}\boldsymbol{k}_{\text {cat }} / \boldsymbol{K}_{\mathbf{m}} \\
(\mathbf{m L} / \mathbf{m g} \cdot \mathbf{s})\end{array}$ \\
\hline Casein & $231.50 \pm 3.07^{\mathrm{a}}$ & $7.37 \pm 0.24^{\mathrm{b}}$ & 0.105 & 0.014 \\
Whey protein & $122.96 \pm 4.98^{\mathrm{b}}$ & $13.35 \pm 1.17^{\mathrm{a}}$ & 0.056 & 0.004 \\
\hline
\end{tabular}

*The measurement of kinetic parameters was carried out using casein and whey protein as substrates at $50^{\circ} \mathrm{C}$ in $0.05 \mathrm{~mol} / \mathrm{L}$ MOPS buffer ( $\left.\mathrm{pH} 8.5\right) . K_{\mathrm{m}}$ and $V_{\max }$ were shown as mean $\pm \mathrm{SD}(n=3)$

accumulation of the alkaline proteases [11]. On the contrary, B. subtilis is a more attractive expression host to steadily secrete extracellular proteins directly into the culture medium [23]. Moreover, the protease activity of GsProS8 was also higher than the other alkaline serine proteases from Aspergillus sojae (400 U/mL) [24], B. subtilis RD7 (607 U/mL) [2], and B. clausii $(1020 \mathrm{U} / \mathrm{mL})$ [25].

After purification, the specific activity of GsProS8 increased from $1697.1 \mathrm{U} / \mathrm{mg}$ to $3559.7 \mathrm{U} / \mathrm{mg}$ (Table 1), which is much higher than the previously reported proteases from G. stearothermophilus strain B-1172 (97.5 U/ mg) [8] and strain F1 (1790 U/mg) [7]. In general, the molecular masses of alkaline serine proteases from bacteria have been reported to be $30-45 \mathrm{kDa}$. Molecular masses of alkaline serine proteases from A. sojae, B. subtilis RD7, and Bacillus lehensis JO-26 were reported to be $35.2 \mathrm{kDa}$ [24], $43 \mathrm{kDa}$ [2], and $34.6 \mathrm{kDa}$ [26], respectively. In this study, the purified GsProS8 had a relative molecular mass of $27.2 \mathrm{kDa}$ on SDS-PAGE and $28.3 \mathrm{kDa}$ in gel filtration (Fig. 3), which presented a good dispersibility and permeability [27]. However, the predicted molecular mass of GsProS8 was same as the protease (100\% identity of amino acid sequences) expressed in $E$. coli $(39 \mathrm{kDa})$ [8]. The conversion of the primary gene product into the mature protease is most likely autocatalytic, and the pro-peptide sequence might be cleaved by a selfprocessing mechanism. Thus, the molecular mass of purified protease did not correspond with the prediction by gene sequence [11]. Tang and co-workers [11] cloned and expressed an alkaline protease gene from $B$. licheniformis 2709 in B. subtilis WB600. The truncation of propeptide was demonstrated by the molecular mass of $30.5 \mathrm{kDa}$ in contrast to the predicted value of $55 \mathrm{kDa}$ [28]. This truncation has also been reported in the keratinolytic protease from Thermoactinomyces sp. YT06, alkaline protease from Vibrio sp. DA1-1, and serine protease from Dichelobacter nodosus, in which the recombinant proteases were $28-37 \mathrm{kDa}$, instead of the expected $40.3-50.6 \mathrm{kDa}$ [29-31]. The keratinase and alkaline protease genes from Thermoactinomyces sp. YT06 and Vibrio sp. DA1-1 were cloned and expressed in $E$. coli BL21, and the pro-sequences were also autoproteolytically cleaved in the periplasm [29, 30]. 
Table 6 Orthogonal experimental results and the optimization of whey protein hydrolysates by GsPros8

\begin{tabular}{|c|c|c|c|c|c|}
\hline \multirow[t]{2}{*}{ Trial } & \multicolumn{4}{|c|}{ Factor } & \multirow{2}{*}{$\begin{array}{l}\text { Peptide } \\
\text { content } \\
\text { (\%) }\end{array}$} \\
\hline & $\mathrm{pH}$ & Temperature $\left({ }^{\circ} \mathrm{C}\right)$ & Time (h) & Whey protein concentration (\%) & \\
\hline 1 & 1 & 1 & 1 & 1 & 15.6 \\
\hline 2 & 2 & 1 & 2 & 2 & 17.0 \\
\hline 3 & 3 & 1 & 3 & 3 & 21.7 \\
\hline 4 & 1 & 2 & 2 & 3 & 33.4 \\
\hline 5 & 2 & 2 & 3 & 1 & 29.2 \\
\hline 6 & 3 & 2 & 1 & 2 & 34.9 \\
\hline 7 & 1 & 3 & 3 & 2 & 31.4 \\
\hline 8 & 2 & 3 & 1 & 3 & 51.5 \\
\hline 9 & 3 & 3 & 2 & 1 & 14.5 \\
\hline $\mathrm{K}_{1}^{\mathrm{a}}$ & 23.5 & 14.8 & 21.6 & 16.4 & \\
\hline $\mathrm{K}_{2}^{\mathrm{a}}$ & 32.6 & 32.5 & 30.7 & 27.8 & \\
\hline $\mathrm{K}_{3}^{\mathrm{a}}$ & 23.7 & 32.5 & 27.4 & 35.5 & \\
\hline$R^{b}$ & 9.1 & 17.7 & 9.0 & 19.1 & \\
\hline The impact of factors & \multicolumn{5}{|c|}{ Whey protein concentration $>$ Temperature $>\mathrm{pH}>$ Time } \\
\hline Optimized hydrolysis condition & \multicolumn{5}{|c|}{$\mathrm{pH} 8.0,60^{\circ} \mathrm{C}, 6 \mathrm{~h}, 11 \%$ of whey protein concentration } \\
\hline
\end{tabular}

${ }^{a} K_{1}, K_{2}$, and $K_{3}$ indicated the sum of peptide contents corresponding to level 1, level 2, and level 3, respectively

${ }^{b} R$ was the correlation coefficient value, $R=\operatorname{Max} K_{i}-\operatorname{Min} K_{i}(i=1,2$, or 3$)$

Therefore, the truncation was not specific to overexpression in B. subtilis WB600.

Species of Bacillus are the most representative microbial strains used in the production of alkaline serine proteases with many applications in food industry, such as hydrolyzing proteins to obtain bioactive ingredients [32] and modifying wheat gluten to improve the texture of baking products [33]. Notably, the majority alkaline serine proteases exhibit optimal $\mathrm{pH}$ in the range of 7 to 11 [27]. The optimal pH 8.5 of GsProS8 is committed to this range, but is slightly lower than the proteases ( $\mathrm{pH} 9.0-$
10.6) from other strains of G. stearothermophilus [6], Bacillus sp. strain B001 [13], B. subtilis RD7 [2], and A. sojae [24]. Meanwhile, the $\mathrm{pH}$ stability of GsProS8 was comparable with the protease from G. stearothermophilus B-1172, in which a high residual activity (> 87\%) was retained after incubation of the proteases at $\mathrm{pH} 5.0-9.0$ [8]. However, the residual activities of the proteases from G. stearothermophilus $\mathrm{F} 1$ and AP-4 kept $95 \%$ of residual activities within $\mathrm{pH} 8.0-10.0[6,7]$.

Furthermore, GsProS8 had a maximal activity at $50^{\circ} \mathrm{C}$ (Fig. 4c), which is lower than those bacterial proteases

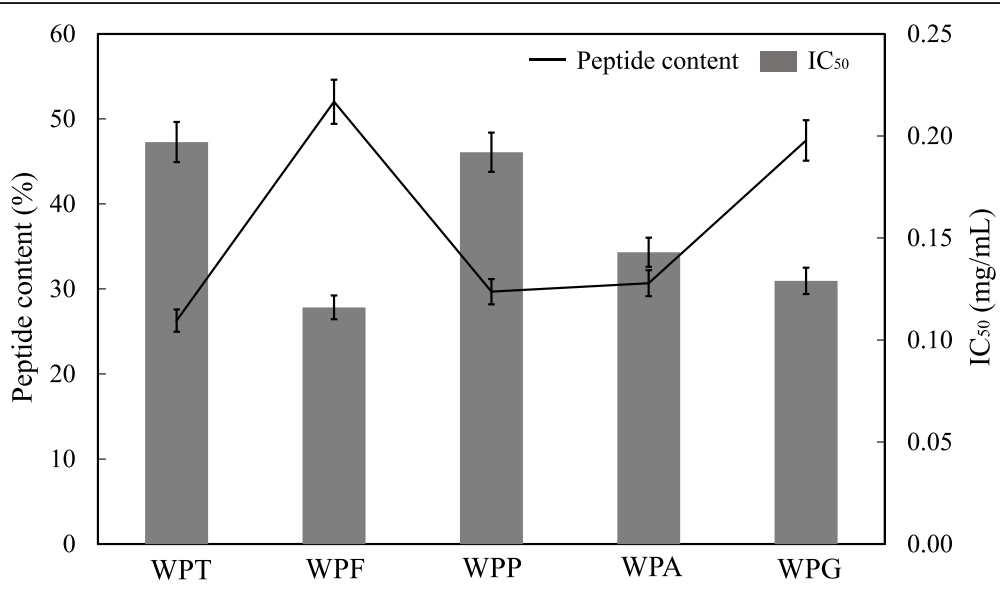

Fig. 5 Peptide contents and $I C_{50}$ values of whey protein hydrolysates prepared by GsProS8 versus commercial proteases. WPT, whey protein hydrolysate prepared by trypsin at $\mathrm{pH} 8.0$ and $37^{\circ} \mathrm{C}$; WPF, whey protein hydrolysate prepared by Flavourzyme at pH 7.0 and $53^{\circ} \mathrm{C}$; WPP, whey protein hydrolysate prepared by Protamex at $\mathrm{pH} 7.5$ and $40^{\circ} \mathrm{C}$; WPA, whey protein hydrolysate prepared by Alcalase at $\mathrm{pH} 8.0$ and $60^{\circ} \mathrm{C} ; \mathrm{WPG}$, whey protein hydrolysate prepared by GsProS8 at $\mathrm{pH} 8.0$ and $60^{\circ} \mathrm{C}$ 
from G. stearothermophilus F1 expressed in $E$. coli $\left(80^{\circ} \mathrm{C}\right)$ and Bacillus sp. strain B001 $\left(60^{\circ} \mathrm{C}\right)$ [7, 13]. In theory, the expression and biochemical properties of proteases are influenced by many factors, such as the strain of expression host, culture temperature, the inducing temperature and time [34]. As the protein expressed in E. coli, the recombinant protease was secreted within cytoplasm as a soluble and active form to maintain the original living temperature of G. stearothermophilus. While expression in B. subtilis, the recombinant protease was extracellularly secreted into culture medium at $37^{\circ} \mathrm{C}$. The optimal temperature of GsProS8 expressed in B. subtilis was deduced. This was also proved by Zhang and co-workers [14], in which the protease (NprT) from G. stearothermophilus expressed in $B$. subtilis DB104 was different from the growth temperature of G. stearothermophilus (Table 7). In addition, the lower molecular mass of GsProS8 (27.2 $\mathrm{kDa})$ was contributed to the lower optimal temperature $\left(50^{\circ} \mathrm{C}\right)$ as compared with the protease gene expressed in E. coli $(39 \mathrm{kDa})$ [8]. A similar finding was reported by Liu and co-workers [35], who compared keratinase gene expression in E. coli, B. subtilis, and P. pastoris. However, GsProS8 was comparable and displayed an even higher optimal temperature than the proteases from $B$. lehensis JO-26 $\left(50{ }^{\circ} \mathrm{C}\right)$ [26], A. sojae expressed in P. pastoris $\left(40{ }^{\circ} \mathrm{C}\right)$ [24], and B. subtilis RD7 expressed in E. coli $\left(40^{\circ} \mathrm{C}\right)$ [2]. Therefore, GsProS8 can be handled for industrial applications under an alkaline condition with a relative high temperature to increase reaction rate.

The protease activity of GsProS 8 relatively remained constant and was not declined too much in the presence of metal ions, except $\mathrm{Cu}^{2+}$ (Table 3). Thus, the protease described in this study is not a metalloenzyme. This is similar with the subtilisins from B. subtilis RD7 [2] and $B$. lehensis JO-26 [26], but better than the one from $\mathrm{Ba}$ cillus spp. B001 [13], whose activities were almost completely reduced by $\mathrm{Cu}^{2+}, \mathrm{Zn}^{2+}, \mathrm{Ni}^{2+}$, and $\mathrm{Co}^{2+}$. The protease activity of GsProS8 was affected in the presence of heavy metal $\mathrm{Cu}^{2+}$, because it might chelate with the protease causing precipitation and deactivation [36]. In addition, the reduction of protease activity in the presence of $\mathrm{Ni}^{2+}, \mathrm{Mn}^{2+}, \mathrm{Co}^{2+}$, and $\mathrm{Zn}^{2+}$ demonstrated that GsProS8 might contain a number of metal ions, so, the displacement or substitution of them compromise the catalysis [2, 8].

GsProS8 was highly specific towards casein and whey protein (Table 4). This may be resulted from the maximization of the binding energy of casein and whey protein for the protease that decided the substrate affinity [8]. The result is in accordance with the alkaline serine proteases from G. stearothermophilus B-1172 and A. sojae showing the highest activities towards casein [8, $24]$. In the meantime, GsProS8 had significant hydrolysis preferences to skim milk powder, hemoglobin, and soybean protein isolate, and relative activities towards BSA, protamine, myoglobin, and azocasein (Table 4). So, it displayed broader substrate specificity than the proteases from B. subtilis RD7 [2], A. sojae [24], and G. stearothermophilus B-1172 [8]. However, azocasein was found to be the most preferred substrate for the protease from $B$. subtilis RD7 [2].

As summarized in literature, the values of $K_{\mathrm{m}}$ and $V_{\max }$ of proteases presented as $0.08-5.10 \mathrm{mg} / \mathrm{mL}$ and 25-7692 U/mg, respectively [37-40]. GsProS8 exhibited higher affinity than the other alkaline serine proteases

Table 7 Alkaline serine proteases from G. stearothermophilus and being used to prepare ACE inhibitory hydrolysates

\begin{tabular}{|c|c|c|c|c|c|c|c|}
\hline $\begin{array}{l}\text { Origin of alkaline serine } \\
\text { protease }\end{array}$ & $\begin{array}{l}\text { Expression } \\
\text { host }\end{array}$ & $\begin{array}{l}\text { Molecular mass } \\
(\mathrm{kDa})\end{array}$ & $\begin{array}{l}\text { Protease } \\
\text { activity } \\
(\mathrm{U} / \mathrm{mL})^{\mathrm{a}}\end{array}$ & $\begin{array}{l}\text { Optimal } \mathrm{pH} \text { and } \\
\text { temperature }\end{array}$ & $\begin{array}{l}\text { Hydrolyzed } \\
\text { protein }^{\mathbf{b}}\end{array}$ & $\begin{array}{l}\mathrm{IC}_{50} \\
(\mathrm{mg} / \mathrm{mL})\end{array}$ & Reference \\
\hline G. stearothermophilus CAU209 & B. subtilis WB600 & 27.2 & 3807 & $\mathrm{pH} 8.5,50^{\circ} \mathrm{C}$ & Whey protein & 0.129 & This study \\
\hline G. stearothermophilus AP-4 & - & - & 250 & $\mathrm{pH} 9.0,55^{\circ} \mathrm{C}$ & - & - & 6 \\
\hline G. stearothermophilus F1 & E.coli XL1-Blue & 27 & 1500 & $\mathrm{pH} 9.0,80^{\circ} \mathrm{C}$ & - & - & 7 \\
\hline G. stearothermophilus B-1172 & E. coli BL21 & 39 & 64 & $\mathrm{pH} 9.0,90^{\circ} \mathrm{C}$ & - & - & 8 \\
\hline G. stearothermophilus & B. subtilis DB104 & 35 & 7020 & $\mathrm{pH} 7.5,65^{\circ} \mathrm{C}$ & - & - & 14 \\
\hline Anoxybacillus kamchatkensis M1V & E. coli BL21 & 28 & 4600 & $\mathrm{pH} 11.0,70^{\circ} \mathrm{C}$ & Shrimp protein & 0.010 & 44,45 \\
\hline Aeribacillus pallidus VP3 & - & 29 & 3000 & $\mathrm{pH} 10.0,60^{\circ} \mathrm{C}$ & Shrimp protein & 0.014 & 45,46 \\
\hline Yarrowia lipolytica & - & 35 & - & $\mathrm{pH} 9.0,45^{\circ} \mathrm{C}$ & Egg white protein & 1.229 & 47,48 \\
\hline Sardina pilchardus & - & 25 & 500 & $\mathrm{pH} 8.0,60^{\circ} \mathrm{C}$ & Sardinelle protein & 1.200 & 49,50 \\
\hline A. clavatus ES1 & E. coli BL21 & 32 & 260 & $\mathrm{pH} 8.5,50^{\circ} \mathrm{C}$ & Sardinelle protein & 7.400 & 38,50 \\
\hline B. licheniformis $\mathrm{NH} 1$ & - & 27 & 1600 & $\mathrm{pH} 10.0,70^{\circ} \mathrm{C}$ & Sardinelle protein & 2.100 & 50,51 \\
\hline
\end{tabular}

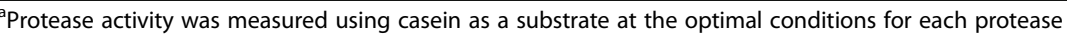

${ }^{\text {b}}$ The protein was hydrolyzed under the optimal hydrolysis condition of each protease

- Not found 
(Table 5), to indicate potential application in commercial products. Additionally, because caseins carried open structures to be susceptible for proteolysis than whey protein with a globular nature [41], the kinetic parameters of GsProS8 acting on whey protein were significantly lower than those on casein.

Proteases have been found to display many applications in the food industry, in which the preparation of protein hydrolysates with remarkable biological activities (e.g., antihypertensive, immunostimulating, antimicrobial, and antioxidant activities) have attracted much attention [1]. Due to excellent nutritional and functional properties, whey protein hydrolysates produced by protease hydrolysis, microbial fermentation, and heat treatment have been widely used in food industry [42]. ACE inhibitory activity of whey protein hydrolysates has been discovered using various proteases (e.g., trypsin, Alcalase, bromelain, papain, and pepsin) [43]. In this study, whey protein was hydrolyzed by GsProS8 and commercial proteases (e.g., trypsin, Flavourzyme, Protamex, and Alcalase), GsProS8 hydrolysate contained higher peptide content and ACE inhibitory activity (Fig. 5). In particular, the whey protein hydrolysate prepared by GsProS8 $\left(\mathrm{IC}_{50}\right.$ of $0.129 \mathrm{mg} / \mathrm{mL}$ ) exhibited better antihypertensive activity than the hydrolysates produced by other alkaline serine proteases from Maclura pomifera $\left(\mathrm{IC}_{50}\right.$ of 0.53 $\mathrm{mg} / \mathrm{mL}$ ) [21] and Cucurbita ficifolia ( $\mathrm{IC}_{50}$ of $0.65 \mathrm{mg} /$ $\mathrm{mL}$ [22]. In addition, GsProS8 was compared with other alkaline serine proteases for the preparation of ACE inhibitory hydrolysates (Table 7). GsProS8 has comparable biochemical properties as compared with alkaline serine proteases from Anoxybacillus kamchatkensis strain M1V and Aeribacillus pallidus strain VP3. Moreover, GsProS8 hydrolyzed whey protein to yield a lower $\mathrm{IC}_{50}$ value $(0.129 \mathrm{mg} / \mathrm{mL})$ than the hydrolysates prepared by the proteases from Yarrowia lipolytica, S. pilchardus, A. clavatus ES1 and B. licheniformis NH1 (1.200-7.400 mg/ $\mathrm{mL})[38,44-51]$. This revealed that GsProS8 has potential to be used for preparation of antihypertensive hydrolysates and peptides.

\section{Conclusions}

In summary, an alkaline serine protease gene from $G$. stearothermophilus CAU209 has been expressed in B. subtilis WB600, to exhibit high protease activity (3807 $\mathrm{U} / \mathrm{mL}$ ) after high cell density fermentation. GsProS8 was purified as a monomeric protein with a molecular mass of $27.2 \mathrm{kDa}$. It showed maximal protease activity at $\mathrm{pH}$ 8.5 and $50{ }^{\circ} \mathrm{C}$ with a broad substrate specificity. Moreover, GsProS8 displayed a good ability to hydrolyze whey protein to prepare antihypertensive hydrolysates. The properties of GsProS8 provided important insights for its applications into food industry.

\section{Methods}

Bacterial strain, plasmids and media

G. stearothermophilus CAU209 was deposited in Key Laboratory of Food Bioengineering (China National Light Industry) in Beijing, China. B. subtilis WB600 ( $\Delta b p r$, $\Delta e p r, \Delta m p r, \Delta n p r B, \Delta v p r, \Delta w p r A)$, a six extracellular protease deficient strain gifted from Guangxi University, Nanning, China, was used as the expression host. E. coli DH5 $\alpha\left[F^{-}\right.$supE44 $\Phi 80$ SlacZ $\triangle M 15 \triangle$ (lacZYA-argF) U169 endA1 recA1 hsdR17 $\left(r_{K}^{-}, m_{K}{ }^{+}\right)$deoR thi-1 $\lambda$ gyrA96 relA1] (Biomed, Beijing, China) was used as the host strain for DNA manipulation, and was cultured in Luria-Bertani (LB) medium composed of $10 \mathrm{~g} / \mathrm{L}$ peptone, $5 \mathrm{~g} / \mathrm{L}$ yeast extract, and $5 \mathrm{~g} / \mathrm{L} \mathrm{NaCl}$. Plasmid pWB980 (TaKaRa Corporation, Dalian, China) was used as the expression vector. Whey protein (80\% of protein content on dry basis) was obtained from Ausnutria Dairy Corporation (Changsha, China). All other chemicals and reagents were of analytical grades and commercially available from Sigma-Aldrich (St. Louis, MO, USA).

\section{Cloning of the alkaline serine protease gene (GsProS8)}

Genomic DNA from G. stearothermophilus CAU209 (GenBank: MW084977) was extracted as described previously [52]. According to the genome sequence of $G$. stearothermophilus CAU209, a pair of oligonucleotide primers, named GsProS8-F and GsProS8-R (Table S1), were designed to amplify the coding region of the alkaline serine protease. Polymerase chain reaction (PCR) was performed at $94{ }^{\circ} \mathrm{C}$ for $5 \mathrm{~min}, 30$ cycles with denaturing at $94{ }^{\circ} \mathrm{C}$ for $30 \mathrm{~s}$, annealing at $56^{\circ} \mathrm{C}$ for $30 \mathrm{~s}$ and extension at $72{ }^{\circ} \mathrm{C}$ for $1.5 \mathrm{~min}$, and the last cycle was at $72^{\circ} \mathrm{C}$ for $10 \mathrm{~min}$. The PCR product was ligated with pMD-19 $\mathrm{T}$ and transformed into E. coli $\mathrm{DH} 5 \alpha$ for sequencing. Sequence analysis was performed using DNAMAN 6.0. The ORF was found using ORF Finder (http://www.ncbi.nlm.nih.gov/gorf/orfig.cgi/). The signal peptide was predicted by SignalP 4.0 (http://www.cbs. dtu.dk/services/SignalP/).

\section{Plasmid construction for expression of GsProS8}

To express the protease gene in B. subtilis WB600, two pairs of primers (GsProS8-IF and GsProS8-IR, pWB980VF and pWB980-VR, Table S1) were designed to amplify the ORF region of the GsProS8 gene on the chromosome DNA and the vector, respectively. The overlapping PCR was carried out using $0.0002 \mathrm{~mol} / \mathrm{L}$ each of the four dNTPs and $0.04 \mathrm{U}$ Phusion DNA polymerase. P43 promoter was located at the upstream of $S a c B$ signal peptide in the plasmid pWB980. PCR conditions were as follows: $94{ }^{\circ} \mathrm{C}$ for $5 \mathrm{~min}, 30$ cycles of $94{ }^{\circ} \mathrm{C}$ for $30 \mathrm{~s}, 56^{\circ} \mathrm{C}$ for $30 \mathrm{~s}, 72^{\circ} \mathrm{C}$ for $1.5 \mathrm{~min}$ (the last cycle at $72{ }^{\circ} \mathrm{C}$ for 10 min). The purified PCR product was digested with EcoRI and SmaI restriction endonucleases, and then inserted 
into the plasmid pWB980. The recombinant plasmid pWB980-GsProS8 was transformed into the B. subtilis WB600 by electroporation. The transformants were cultured on LB plates and incubated at $37{ }^{\circ} \mathrm{C}$ until colonies appeared. The colonies were then suspended in the LB medium for further growth in a rotary shaker at $37^{\circ} \mathrm{C}$ for $18-24 \mathrm{~h}$. The cultures were centrifuged at $10,000 \times g$ for $10 \mathrm{~min}$ to collect the supernatant. The protease activity as well as the expression in the supernatant were analyzed by the Folin-Ciocalteu reagent and SDS-PAGE, respectively.

\section{High cell density fermentation}

To scale up GsProS8 production, high cell density fermentation was carried out in a $5.0 \mathrm{~L}$ fermentor (Guoqiang, Shanghai, China) with a $1.5 \mathrm{~L}$ working volume at $37^{\circ} \mathrm{C} .1 \%(\mathrm{v} / \mathrm{v})$ inoculum was initially incubated at $37^{\circ} \mathrm{C}$ for $12 \mathrm{~h}$. Subsequently, the fermentor was inoculated with $750 \mathrm{~mL}$ of the inoculum and cultivated at $37^{\circ} \mathrm{C}$ for $114 \mathrm{~h}$. The fermentation medium was composed of glucose $(10 \mathrm{~g} / \mathrm{L})$, yeast extract powder $(10 \mathrm{~g} / \mathrm{L})$, peptone $(20$ $\mathrm{g} / \mathrm{L})$, corn steep powder $(5 \mathrm{~g} / \mathrm{L})$, sodium chloride $(10 \mathrm{~g} /$ $\mathrm{L})$, magnesium sulfate $(0.3 \mathrm{~g} / \mathrm{L})$, sodium phosphate $(6 \mathrm{~g} /$ $\mathrm{L})$, and dipotassium phosphate $(3 \mathrm{~g} / \mathrm{L})$. The cultivation was maintained at pH 7.0-7.2 with the aid of ammonium hydroxide and phosphoric acid. The dissolved oxygen level was maintained at 30\% air-saturation. Samples were withdrawn at $6 \mathrm{~h}$ interval to analyze enzyme activity, cell mass, and protein concentration, and SDS-PAGE was also performed.

\section{Purification of GsProS8}

The fermented culture was purified through ammonium sulfate precipitation and a two-step chromatographic method. In short, the crude enzyme was initially precipitated by ammonium sulphate $(40-70 \% \mathrm{w} / \mathrm{v}$ saturation) and dialyzed against $0.02 \mathrm{~mol} / \mathrm{L}$ Tris- $\mathrm{HCl}$ at $\mathrm{pH} 8.0$ (buffer A) for overnight. Thereafter, the dialyzed sample was subjected to a HiTrap SP Fast Flow (SPFF) column (GE Healthcare, Wuxi, China), which was pre-equilibrated with buffer A. After washing with buffer A until the absorbance (at $280, \mathrm{OD}_{280}$ ) $<0.05$, the bounded proteins were then eluted with a linear gradient $(0-0.25 \mathrm{~mol} / \mathrm{L})$ of $\mathrm{NaCl}$ at a flow rate of $1 \mathrm{~mL} / \mathrm{min}$. The fraction with high protease activity was collected and dialyzed against $0.05 \mathrm{~mol} / \mathrm{L} \mathrm{N}$-cyclohexyl-3-aminopropanesulfonic acid (CAPS) at pH 10.3 (buffer B) for overnight. The sample was loaded onto a HiTrap Q-Sepharose Fast Flow (QSFF) column (GE Healthcare, Wuxi, China) that was pre-equilibrated with buffer B. Subsequently, the proteins were eluted with buffer $\mathrm{B}$ until $\mathrm{OD}_{280}<0.05$, followed by a gradient elution of $\mathrm{NaCl}(0-0.15 \mathrm{~mol} / \mathrm{L})$ at $1 \mathrm{~mL} / \mathrm{min}$. The purity of the fractions was verified by SDS-PAGE.
SDS-PAGE, zymogram and molecular mass determination SDS-PAGE was used to evaluate the purity and molecular mass of the protease. The protein bands were stained by Coomassie Brillaint Blue R-250. The molecular weight markers for electrophoresis included $\alpha$-lactalbumin (14.4 $\mathrm{kDa})$, trypsin inhibitor $(20.1 \mathrm{kDa})$, carbonic anhydrase $(29.0 \mathrm{kDa})$, ovalbumin $(44.3 \mathrm{kDa}), \mathrm{BSA}(66.4 \mathrm{kDa})$ and phosphorylase B $(97.2 \mathrm{kDa})$. Zymogram of the protease was analyzed using the SDS-polyacrylamide gel copolymerized with $0.1 \%$ gelatin as described by Sun and coworkers [53]. The native molecular mass of the purified GsProS8 was estimated by a gel filtration chromatography via a Sephacryl S-100 column $(1.0 \times 100 \mathrm{~cm})$. The purified protease and protein markers were eluted by $20 \mathrm{mM}$ Tris$\mathrm{HCl}$ buffer (at pH 8.0) containing $500 \mathrm{mM} \mathrm{NaCl}$ at a flow rate of $0.33 \mathrm{~mL} / \mathrm{min}$.

\section{Protease assay and protein determination}

Protease activity was determined using casein as a substrate. Briefly, the protease solution $(100 \mu \mathrm{L})$ was incubated with $2 \%(\mathrm{w} / \mathrm{v})$ casein $(100 \mu \mathrm{L})$ in $20 \mathrm{mM}$ phosphate buffer $(700 \mu \mathrm{L}, \mathrm{pH} 7.5)$ at $37^{\circ} \mathrm{C}$ for $30 \mathrm{~min}$. The reaction was terminated by trichloroacetic acid $(10 \% \mathrm{w} / \mathrm{v}, 200 \mu \mathrm{L})$. After centrifugation at $10,000 \times \mathrm{g}$ for $5 \mathrm{~min}$, the supernatant $(100 \mu \mathrm{L})$ was mixed with $600 \mu \mathrm{L}$ alkaline reagent $\left(0.4 \mathrm{~mol} / \mathrm{L} \mathrm{Na}_{2} \mathrm{CO}_{3}\right.$ : Folin-Ciocalteu reagent $=5: 1 \mathrm{v} / \mathrm{v}$ ) and incubated at $40{ }^{\circ} \mathrm{C}$ for $20 \mathrm{~min}$. The absorbance was measured at $660 \mathrm{~nm}$ using a spectrophotometer (TU1901, Puxi General Instruments Co., Ltd., Beijing, China). The mixture without the protease was used as control. One unit of protease activity (U) was defined as the amount of the protease to liberate $1 \mu \mathrm{mol}$ tyrosine per minute at the above conditions. Moreover, the protein concentration was measured by the Lowry method using BSA as standard. Specific activity was expressed as units per milligram of protein.

\section{Biochemical properties of GsProS8}

The optimal $\mathrm{pH}$ for protease activity was evaluated at $40^{\circ} \mathrm{C}$ in a $\mathrm{pH}$ range of $4.0-11.0$. The following buffers $(0.05 \mathrm{~mol} / \mathrm{L})$ were used: citrate $(\mathrm{pH} 4.0-5.0)$, acetate $(\mathrm{pH}$ 5.0-5.5), 2-(N-morpholino) ethanesulfonic acid (MES, $\mathrm{pH}$ 5.5-7.0), 4-(N-morpholino) propanesulfonic acid (MOPS, pH 7.0-8.5), and N-cyclohexyl-2-aminoethanesulfonic acid (CHES, $\mathrm{pH} 8.5-11.0$ ). The $\mathrm{pH}$ stability was investigated after incubating the protease in various buffers $(0.05 \mathrm{~mol} / \mathrm{L})$ at $40^{\circ} \mathrm{C}$ for $30 \mathrm{~min}$. The residual activity was determined by the standard assay.

The optimal temperature was determined in $0.05 \mathrm{~mol} /$ $\mathrm{L}$ of MOPS (pH 8.5) buffer at $30-70^{\circ} \mathrm{C}$. The thermostability was measured after incubating the protease at a temperature range of $30-80{ }^{\circ} \mathrm{C}$ for $30 \mathrm{~min}$. The residual activity was determined by the standard assay. 
The effect of several inhibitors on the protease activity was analyzed. The following inhibitors were used: pepstain A (at $0.01 \mathrm{mM}$ and $0.02 \mathrm{mM}$ ), EDTA (at $1 \mathrm{mM}$ and $4 \mathrm{mM}$ ), PMSF (at $1 \mathrm{mM}$ and $4 \mathrm{mM}$ ), and iodoacetamide (at $1 \mathrm{mM}$ and $4 \mathrm{mM}$ ). Moreover, the effect of metal ions on protease activity was examined in the presence of magnesium sulfate, calcium chloride, sodium chloride, nickel chloride, manganese sulfate, cobalt chloride, zinc sulfate, and copper sulfate at the final concentration of $0.001 \mathrm{~mol} / \mathrm{L}$.

Substrate specificity was evaluated at $\mathrm{pH} 8.5$ and $50{ }^{\circ} \mathrm{C}$ using casein, whey protein, skim milk powder, hemoglobin, soybean protein isolate, BSA, protamine, myoglobin, azocasein, or gelatin $(1 \% \mathrm{w} / \mathrm{v})$. The protease activity was measured as described previously. The protease activity towards casein was determined to be $100 \%$, to calculate the relative protease activities to other substrates.

\section{Kinetic parameters of GsProS8}

The kinetic parameters of the purified GsProS8 were determined using Michaelis-Menten plot after measuring the protease activities at various concentrations of casein $(4-16 \mathrm{mg} / \mathrm{mL})$ and whey protein $(8-25 \mathrm{mg} / \mathrm{mL})$ at $\mathrm{pH}$ 8.5 and $50{ }^{\circ} \mathrm{C}$ for $5 \mathrm{~min}$. The parameters included $K_{\mathrm{m}}$, $V_{\text {max }}, k_{\text {cat }}$ and $k_{\text {cat }} / K_{\mathrm{m}}$, in which $K_{\mathrm{m}}$ and $V_{\text {max }}$ were obtained from non-linear regression analysis by GraphPad Prism V.8 [54].

\section{Hydrolysis of whey protein by GsProS8}

According to the preliminary test, $\mathrm{pH}$, temperature, time, and whey protein concentration were identified as four critical factors to impact the hydrolysis of whey protein by GsProS8. Each factor was analyzed at three levels using an orthogonal experimental design (Table S2). In brief, whey protein $(7-11 \%, \mathrm{w} / \mathrm{v})$ was hydrolyzed by GsProS8 $(200 \mathrm{U} / \mathrm{mL})$ at designed temperature (40$60{ }^{\circ} \mathrm{C}$ ) and $\mathrm{pH}(7.5-8.5)$ for $4-8 \mathrm{~h}$ in a temperaturecontrol shaker (HZQ-X100, Suzhou, China) at $100 \mathrm{rpm}$, and terminated by heating at $85^{\circ} \mathrm{C}$ for $10 \mathrm{~min}$. The hydrolysate solutions were centrifuged (Refrigerated Centrifuge GL-20B, Shanghai, China) at $10,000 \times$ g for $10 \mathrm{~min}$ to obtain the supernatants for later analysis. Commercial proteases $\left(200 \mathrm{U} / \mathrm{mL}\right.$, e.g., trypsin at $\mathrm{pH} 8.0$ and $37^{\circ} \mathrm{C}$; Flavourzyme at $\mathrm{pH} 7.0$ and $53^{\circ} \mathrm{C}$; Protamex at $\mathrm{pH} 7.5$ and $40^{\circ} \mathrm{C}$; and Alcalase at $\mathrm{pH} 8.0$ and $60^{\circ} \mathrm{C}$ ) were also applied in the hydrolysis of whey protein.

\section{Peptide content of whey protein hydrolysate}

The peptide content in the whey protein hydrolysate was determined by o-phthalaldehyde (OPA) method as described by Church and co-workers [55] with slight modifications. Concisely, the supernatant of whey protein hydrolysate $(25 \mu \mathrm{L})$ was added into OPA mixture $(1 \mathrm{~mL})$, which was prepared by $100 \mathrm{mM}$ sodium tetraborate, $20 \%$ (w/w) SDS, and OPA solution (containing 0.02\% w/v OPA, methanol, and $\beta$-mercaptoethanol). The incubation was then processed at room temperature for $8 \mathrm{~min}$, and the absorbance of resulting solution at $340 \mathrm{~nm}$ (TU1800PC spectrophotometer, Persee General Instrument Co. Ltd., Beijing, China) was recorded. Both distilled water and glutathione were performed as a blank and a standard, respectively. The peptide content was calculated based on the standard curve of glutathione.

\section{Antihypertensive activity of whey protein hydrolysate}

Antihypertensive activity of whey protein hydrolysate was expressed as ACE inhibitory activity (\%) and measured as described by Cushman and Cheung [56] with some modifications. Namely, the reaction of whey protein hydrolysate $(2 \mathrm{mg} / \mathrm{mL}, 20 \mu \mathrm{L})$ with $\mathrm{ACE}(0.1 \mathrm{U} / \mathrm{mL}$, $10 \mu \mathrm{L}$ ) in $120 \mu \mathrm{L}$ of $0.1 \mathrm{M}$ sodium borate buffer (containing $5 \mathrm{mMN}$-Hippuryl-His-Leu hydrate and $0.3 \mathrm{M} \mathrm{NaCl}$ at $\mathrm{pH} 8.3$ ) was performed at $37^{\circ} \mathrm{C}$ for $60 \mathrm{~min}$. The reaction was then terminated by $\mathrm{HCl}(1 \mathrm{M}, 150 \mu \mathrm{L})$ and ethyl acetate $(1 \mathrm{~mL})$, followed by centrifugation (GL-20B Refrigerated Centrifuge, Anting Scientific Instrument Co. Ltd., Shanghai, China) at $4000 \mathrm{rpm}$ for $10 \mathrm{~min}$ at room temperature to collect the supernatant, which was dried at $105{ }^{\circ} \mathrm{C}$ for $30 \mathrm{~min}$. The liberated hippuric acid was dissolved in the deionized water $(0.5 \mathrm{~mL})$ to record the absorbance at $228 \mathrm{~nm}$ (TU-1800PC, Persee General Instrument Co. Ltd., Beijing, China). The enzyme reaction without the whey protein hydrolysate and sodium borate buffer $(0.1 \mathrm{M})$ containing substrate were used as a control and a blank, respectively. ACE inhibitory activity (\%) was calculated as follows:

$$
\text { ACE inhibitory activity }(\%)=\frac{A_{b}-A_{a}}{A_{b}-A_{c}} \times 100 \%
$$

where $A_{a}$ is the absorbance of the sample supernatant, $A_{b}$ is the absorbance of the control, and $A_{c}$ is the absorbance of the blank. ACE inhibitory activity (\%) was transformed to $\mathrm{IC}_{50}(\mathrm{mg} / \mathrm{mL}$, half maximal inhibitory concentration) based on a plot of relative ACE inhibitory activity (\%) against different dilutions (0.01-1.00\%) of the hydrolyzed supernatant using non-linear regression analysis by GraphPad Prism V.8 (Fig. S5).

\section{Statistics}

The experiments were performed in triplicate and expressed as the mean \pm one standard deviation. A oneway analysis of variance (ANOVA) was carried out using Systat v10 software (San Jose, CA, USA) to analyze statistical differences on the protease activity, peptide 
content, and $\mathrm{ACE}$ inhibitory activity $\left(\mathrm{IC}_{50}\right) . p<0.05$ was considered significant.

\section{Supplementary Information}

The online version contains supplementary material available at https://doi. org/10.1186/s12896-021-00678-7.

\section{Additional file 1.}

\section{Abbreviations}

PMSF: Phenylmethylsulfonylfluoride; DFP: Diodopropyl fluorophosphate: GRAS: Generally recognized as safe; ACE: Angiotensin-I-converting enzyme; LB: Luria-Bertani; PCR: Polymerase chain reaction; ORF: Open reading frame; SDS-PAGE: Sodium dodecyl sulphate-polyacrylamide gel electrophoresis; SPFF: SP Fast Flow; CAPS: N-cyclohexyl-3-aminopropanesulfonic acid; QSFF: Q-Sepharose Fast Flow; BSA: bovine serum albumin; MES: 2-(Nmorpholino) ethanesulfonic acid; MOPS: 4-(N-morpholino) propanesulfonic acid; CHES: N-cyclohexyl-2-aminoethanesulfonic acid; EDTA: Ethylenediaminetetraacetic acid; OPA: O-phthaladehyde; ANOVA: A one-way analysis of variance

\section{Acknowledgements}

Not applicable.

\section{Authors' contributions}

CC: Manuscript writing, revision, and data interpretation; SYG and ZPL: Performing experiments, data collection and analysis; QJY and ZQJ: Study design, manuscript editing, and supervision. All authors read and approved the final manuscript

\section{Authors' information}

CC: specialized on the protein science and development of bioactive peptides, Assistant Professor, College of Food Science and Nutritional Engineering, China Agricultural University, Beijing, China. SYG: Master Graduate, College of Food Science and Nutritional Engineering, China Agricultural University, Beijing, China. ZPL: Master Student, College of Food Science and Nutritional Engineering, China Agricultural University, Beijing, China. QJY: Professor, College of Engineering, China Agricultural University, Beijing, China. ZQJ: specialized on the food enzymology, Professor, College of Food Science and Nutritional Engineering, China Agricultural University, Beijing, China.

\section{Funding}

This work was supported by the National Key Research and Development Program of China (2017YFD0400200).

\section{Availability of data and materials}

The sequencing data of the alkaline serine protease gene (GsProS8) from G. stearothermophilus is presented on the NCBI database (GenBank accession number MW084977). The datasets used and/or analyzed during the current study are available from the corresponding author on reasonable request.

\section{Ethics approval and consent to participate}

Not applicable.

\section{Consent for publication}

Not applicable.

\section{Competing interests}

The authors declare that they have no competing interests.

\section{Author details}

'Key Laboratory of Food Bioengineering (China National Light Industry), College of Food Science and Nutritional Engineering, China Agricultural University, No. 17 Qinghua Donglu, Beijing 100083, China. ${ }^{2}$ Beijing Advanced Innovation Center for Food Nutrition and Human Health, College of Engineering, China Agricultural University, Beijing 100083, China.
Received: 6 October 2020 Accepted: 3 February 2021

Published online: 11 March 2021

\section{References}

1. Contesini FJ, de Melo RR, Sato HH. An overview of Bacillus proteases: from production to application. Crit Rev Biotechnol. 2018;38(3):321-34.

2. Suberu Y, Akande I, Samuel T, Lawal A, Olaniran A. Cloning, expression, purification and characterization of serine alkaline protease from Bacillus subtilis RD7. Biocatal Agric Biotechnol. 2019:20:101264.

3. Kolkman M, Mejldal R, Goedegebuur F, Babe LM, Kellett-Smith AH, Mulder $\mathrm{H}$, Bott RR, Scotcher MC. Serine proteases of the Bacillus gibsonii-clade: Danisco US Inc., US10533165; 2016.https://patentimages.storage.googleapis. com/7c/6b/c8/ea8c5f68ea0e1b/US10533165.pdf.

4. Soo JK, Soon WK, Seung BH, Soon JS, Ji YM. New Bacillus subtilis KJ-21 strain useful as microbial agent to produce fermented food i.e. meju or Korean miso, doenjang, seasoned miso, gochujang, seasoned gochujang, spring roll, cheonggukjang, mixed roll, and Korean-style soy sauce: Rural Dev Administration, KR1740543-B1; 2017. https://patentimages.storage.googlea pis.com/e7/f4/4d/d6a38cecd0b761/KR101740543B1.pdf.

5. Maynard F, Salvatore D, Thevenier A, Salvato D. Methods of preparing milk protein hydrolysate for composition e.g. infant formula involves hydrolyzing milk-based proteinaceous material with microbial alkaline serine protease in combination with bromelain and protease from Aspergillus: Nestec SA, AU2020267141-A1; 2020.https://patentimages.storage.googleapis.com/c7/ 74/20/f20c0d21843ed6/AU2020267141A1.pdf.

6. Dhandapani R, Vijayaragavan R. Production of a thermophilic, extracellular alkaline protease by Bacillus stearothermophilus AP-4. World J Microbiol Biotechnol. 1994;10(1):33-5.

7. Fu ZB, Hamid SBA, Bazak CNA, Basri M, Salleh AB, Rahman RNZA. Secretory expression in Escherichia coli and single-step purification of a heat-stable alkaline protease. Protein Expr Purif. 2003;28(1):63-8.

8. Iqbal I, Aftab MN, Afzal M, Ur-Rehman A, Aftab S, Zafar A, Ud-Din Z, Khuharo AR, lqbal J, UI-Haq I. Purification and characterization of cloned alkaline protease gene of Geobacillus stearothermophilus. J Basic Microbiol. 2015; 55(2):160-71.

9. Rahman RNZA, Razak CN, Ampon K, Basri M, Yunus WMZW, Salleh AB. Purification and characterization of a heat-stable alkaline protease from Bacillus stearothermophilus F1. Appl Microbiol Biotechnol. 1994;40(6):822-7.

10. Latiffi AA, Salleh AB, Rahman RNZRA, Oslan SN, Basri M. Secretory expression of thermostable alkaline protease from Bacillus stearothermophilus F1 by using native signal peptide and a-factor secretion signal in Pichia pastoris. Genes Genet Syst. 2013;88(2):85-91.

11. Tang XM, Shen W, Lakay FM, Shao WL, Wang ZX, Prior BA, Zhuge J. Cloning and over-expression of an alkaline protease from Bacillus licheniformis. Biotechnol Lett. 2004;26(12):975-9.

12. Zhou CX, Zhou HY, Li DK, Zhang HT, Wang HB, Lu FP. Optimized expression and enhanced production of alkaline protease by genetically modified Bacillus licheniformis 2709. Microb Cell Factories. 2020;19(1):45.

13. Deng A, Wu J, Zhang GQ, Wen TY. Molecular and structural characterization of a surfactant-stable high-alkaline protease AprB with a novel structural feature unique to subtilisin family. Biochimie. 2011;93(4):783-91.

14. Zhang M, Zhao C, Du LX, Lu FP, Gao C. Expression, purification, and characterization of a thermophilic neutral protease from Bacillus stearothermophilus in Bacillus subtilis. Sci China C Life Sci. 2008;51(1):52-9.

15. Du H, Lu Y, Fan Y, Fu Q, Qiao B, Du X. New Bacillus subtilis expressing foreign protein, produced by performing gene knockout of two exocrine protease encoding genes including alkaline serine protease (subtilisin E) (aprE) gene and neutral metalloprotease (nprE) gene: Genscript Nanjing Co Ltd, CN104073458-A; 2014. https://patentimages.storage.googleapis.com/8d/ ff/fc/1f26e8047ada06/CN104073458A.pdf.

16. Lu F, Li Y, Wang X, Shi C, Yu J, Liu Y, Peng C, Liu F, Zhang H, Wang H. New genetically engineered bacterium useful for fermentation production of alkaline proteases and constructing comprising e.g. synthetic nucleotide sequence and a signal peptide combination and using Bacillus clausi genome as template: Univ Tianjin Sci \& Technology, CN110144319-A; 2019. https://patentimages.storage.googleapis.com/c4/69/42/90b67eb31d4f67/ CN110144319A.pdf.

17. Rekik H, Jaouadi NZ, Gargouri F, Bejar W, Frikha F, Jmal N, Bejar S, Jaouadi B. Production, purification and biochemical characterization of a novel detergent-stable serine alkaline protease from Bacillus safensis strain RH12. Int J Biol Macromol. 2019;121:1227-39. 
18. Jaouadi B, Ellouz-Chaabouni S, Ali MB, Messaoud EB, Naili B, Dhouib A, Bejar S. Excellent laundry detergent compatibility and high dehairing ability of the Bacillus pumilus CBS alkaline proteinase (SAPB). Biotechnol Bioproc E. 2009:14:503-12.

19. Nwachukwu ID, Aluko RE. Structural and functional properties of food protein-derived antioxidant peptides. J Food Biochem. 2019:43(1):e12761.

20. Lermen AM, Clerici NJ, Daroit DJ. Biochemical properties of a partially purified protease from Bacillus sp. CL18 and its use to obtain bioactive soy protein hydrolysates. Appl Biochem Biotechnol. 2020;192(2):643-64.

21. Bertucci Jl, Liggieri CS, Colombo ML, Cavalli SEV, Bruno MA. Application of peptidases from Maclura pomifera fruit for the production of active biopeptides from whey protein. LWT Food Sci Technol. 2015;64(1):157-63.

22. Konrad B, Anna D, Marek S, Marta P, Aleksandra Z, Jozefa C. The evaluation of dipeptidyl peptidase (DPP)-IV, a-glucosidase and angiotensin converting enzyme (ACE) inhibitory activities of whey proteins hydrolyzed with serine protease isolated from Asian pumpkin (Cucurbita ficifolia). Int J Rept Res Ther. 2014:20:483-91.

23. Drejer EB, Hakvag S, Irla M, Brautaset T. Genetic tools and techniques for recombinant expression in thermophilic bacillaceae. Microorganisms. 2018, 6(2):1-19.

24. Ke Y, Yuan XM, Li JS, Zhou W, Huang XH, Wang T. High-level expression, purification, and enzymatic characterization of a recombinant Aspergillus sojae alkaline protease in Pichia pastoris. Protein Expr Purif. 2018;148:24-9.

25. Abbasi-Hosseini SM, Eftekhar F, Yakhchali B, Minai-Tehrani D. Cloning and enhanced expression of an extracellular alkaline protease from a soil isolate of Bacillus clausii in Bacillus subtilis. Iran J Biotechnol. 2011;9(40):275-80

26. Bhatt HB, Singh SP. Cloning, expression, and structural elucidation of a biotechnologically potential alkaline serine protease from a newly isolated haloalkaliphilic Bacillus lehensis JO-26. Front Microbiol. 2020;11:941.

27. Gimenes NC, Silveira E, Tambourgi EB. An overview of proteases: production, downstream processes and industrial applications. Sep Purif Rev. 2019:00:1-21.

28. Sareen R, Bornscheuer UT, Mishra P. Cloning, functional expression and characterization of an alkaline protease from Bacillus licheniformis. Biotechnol Lett. 2005;27(23-24):1901-7.

29. Chen XJ, Zhou C, Xue YF, Shi JS, Ma YH. Cloning, expression, and characterization of an alkaline protease, AprV, from Vibrio sp. DA1-1. Bioprocess Biosyst Eng. 2018;41:1437-47.

30. Wang L, Zhou Y, Huang Y, Wei QS, Huang HY, Guo CB. Cloning and expression of a thermostable keratinase gene from Thermoactinomyces sp. YT06 in Escherichia coli and characterization of purified recombinant enzymes. World J Microbiol Biotechnol. 2019;35:135.

31. Wani AH, Sharma M, Salwan R, Singh G, Chahota R, Verma S. Cloning, expression, and functional characterization of serine protease Aprv2 from virulent isolate Dichelobacter nodosus of Indian origin. Appl Biochem Biotechnol. 2016;180:576-87.

32. Zheng LF, Yu XY, Wei CH, Qiu LY, Yu CW, Xing Q, Fan YW, Deng ZY. Production and characterization of a novel alkaline protease from a newly isolated Neurospora crassa through solid-state fermentation. LWT Food Sci Technol. 2020;122:108990.

33. Verbauwhede AE, Lambrecht MA, Fierens E, Hermans S, Shegay O, Brijs K, Delcour JA. Thermo-reversible inhibition makes aqualysin 1 from Thermus aquaticus a potent tool for studying the contribution of the wheat gluten network to the crumb texture of fresh bread. Food Chem. 2018;264:118-25.

34. Cui YL, Luo LL, Wang X, Lu YY, Yi YL, Shan YY, Liu BF, Zhou Y, Lv X. Mining, heterologous expression, purification, antibactericidal mechanism, and application of bacteriocins: a review. Comp Rev Food Sci Food Safety. 2020. https://doi.org/10.1111/1541-4337.12658.

35. Liu BH, Zhang J, Gu L, Du GC, Chen J, Liao XR. Comparative analysis of bacterial expression systems for keratinase production. Appl Biochem Biotechnol. 2014;173:1222-35.

36. Pandey S, Ghosh PK, Ghosh S, De TK, Maiti TK. Role of heavy metal resistant Ochrobactrum sp. and Bacillus spp. strains in bioremediation of a rice cultivar and their PGPR like activities. J Microbiol. 2013;51(1):11-7.

37. Li F, Yang L, Lv X, Liu D, Xia H, Chen S. Purification and characterization of a novel extracellular alkaline protease from Cellulomonas bogoriensis. Protein Expr Purif. 2016;121:125-32.

38. Hajji M, Hmidet N, Jellouli K, Vallaeys T, Nasri M, Sellami-Kamoun A. Gene cloning and expression of a detergent stable alkaline protease from Aspergillus clavatus ES1. Process Biochem. 2010;45:1746-52.
39. Kannan K, Jasra RV. Immobilization of alkaline serine endopeptidase from Bacillus licheniformis on SBA-15 and MCF by surface covalent binding. J Mol Catal B. 2009;56(1):34-40.

40. Tarrahimofrad H, Meimandipour A, Arjmand S, Nassiri MB, Jahangirian E, Tavana H, Zamani J, Rahimnahal S, Aminzadeh S. Structural and biochemical characterization of a novel thermophilic Coh01147 protease. PLoS One. 2020;15(6):e0234958.

41. Barros RM, Malcata FX. A kinetic model for hydrolysis of whey proteins by cardosin a extracted from Cynara cardunculus. Food Chem. 2004;88(3):351-9.

42. Sarmadi B, Ismail A. Antioxidative peptides from food proteins: a review. Peptides. 2010;31(10):1949-56.

43. Shu GW, Huang J, Bao CJ, Meng JP, Chen H, Cao JL. Effect of different proteases on the degree of hydrolysis and angiotensin I-converting enzymeinhibitory activity in goat and cow milk. Biomolecules. 2018;8(4):101.

44. Mechri S, Bouacem K, Zarai Jaouadi N, Rekik H, Berrouina MB, Omrane Benmrad M, Hacene H, Bejar S, Bouanane-Darenfed A, Jaouadi B. Identification of a novel protease from the thermophilic Anoxybacillus kamchatkensis M1V and its application as laundry detergent additive. Extremophiles. 2019;23:687-706.

45. Mechri S, Sellem I, Bouacem K, Jabeur F, Chamkha M, Hacene H, BouananeDarenfed A, Jaouadi B. Antioxidant and enzyme inhibitory activities of Metapenaeus monoceros by-product hydrolysates elaborated by purified alkaline proteases. Waste Biomass Valor. 2020;11:6741-55

46. Mechri S, Berrouina MB, Benmarad MO, Jaouadi NZ, Rekik H, Moujehed E, Chebbi A, Sayadi S, Chamkha M, Bejar S, Jaouadi B. Characterization of a novel protease from Aeribacillus pallidus strain VP3 with potential biotechnological interest. Int J Biol Macromol. 2017;94:221-32.

47. Bessadok B, Masri M, Breuck T, Sadok S. Characterization of the crude alkaline extracellular protease of Yarrowia lipolytica YITun15. J Fish Sci. 2017; 11(4):19-24.

48. Pokora M, Zambrowicz A, Zablocka A, Dabrowska A, Szoltysik M, Babij K, Echert E, Trziszka T, Chrzanowska J. The use of serine protease from Yarrowia lipolytica yeast in the production of biopeptides from denatured egg white proteins. Acta Biochim Pol. 2017;62(2):245-53.

49. Bougatef A, Souissi N, Fakhfakh N, Triki-Ellouz Y, Nasri M. Purification and characterization of trypsin from the viscera of sardine (Sardina pilchardus). Food Chem. 2007:102:343-50.

50. Bougatef A, Nedjar-Arroume N, Ravallec-Ple R, Leroy Y, Guillochon D, Barkia A, Nasri M. Angiotensin I-converting enzyme (ACE) inhibitory activities of sardinella (Sardinella aurita) by-products protein hydrolysates obtained by treatment with microbial and visceral fish serine proteases. Food Chem. 2008:111:350-6

51. El Hadj-Ali N, Agrebi R, Ghorbel-Frikha B, Sellami-Kamoun A, Kanoun S, Nasri M. Biochemical and molecular characterization of a detergent stable alkaline seine-protease from a newly isolated Bacillus licheniformis NH1. Enzyme Microb Tech. 2007:40:515-23.

52. Li WJ, Xu P, Schumann P, Zhang YQ, Pukall R, Xu LH, Stackebrandt E, Jiang $\mathrm{CL}$. Georgenia ruanii sp nov., a novel actinobacterium isolated from forest soil in Yunnan (China), and emended description of the genus Georgenia. Int J Syst Evol Microbiol. 2007;57:1424-8.

53. Sun Q, Zhang B, Yan QJ, Jiang ZQ. Comparative analysis on the distribution of protease activities among fruits and vegetable sources. Food Chem. 2016;213:708-13.

54. Lineweaver $H$, Burk D. The determination of enzyme dissociation constant. J Am Chem Sci. 1934;56:665-6.

55. Church FC, Swaisgood HE, Porter DH, Catignani GL. Spectrophotometric assay using o-phthaldialdehyde for determination of proteolysis in milk and isolated milk proteins. J Dairy Sci. 1983;66(6):1219-27.

56. Cushman DW, Cheung HS. Spectrophotometric assay and properties of angiotensin-converting enzyme of rabbit lung. Biochem Pharmacol. 1971; 20(7):1637-48

\section{Publisher's Note}

Springer Nature remains neutral with regard to jurisdictional claims in published maps and institutional affiliations. 